ISSN 1678-3921

Journal homepage: www.embrapa.br/pab

For manuscript submission and journal contents, access: www.scielo.br/pab

Pablo Tavares Costa(1凶) (iD, Gilson de Mendonça ${ }^{(2)}$ (iD, Larissa Picada Brum(3) (iD), Thiago Pereira Vieira ${ }^{(4)}$ (iD, Fernanda Dornelles Feijó(5) (iD and Ricardo Zambarda Vaz $^{(6)}$ (D)

(1) Universidade Federal de Pelotas, Faculdade de Agronomia Eliseu Maciel, Departamento de Zootecnia, Campus Universitário, Avenida Eliseu Maciel, s/no, CEP 96010-900 Capão do Leão, RS, Brazil.

E-mail: pablocostta@hotmail.com

(2) Universidade Federal de Pelotas, Faculdade de Agronomia Eliseu Maciel, Instituto de Biologia, Campus Universitário, Avenida Eliseu Maciel, s/nº, CEP 96010-900 Capão do Leão, RS, Brazil.

E-mail: gilsondemendonca@gmail.com

(3) Universidade Federal do Pampa, Departamento de Zootecnia, Campus Dom Pedrito, Rua 21 de abril, № 80, CEP 96450000 Dom Pedrito, RS, Brazil.

E-mail: Ipbrum@hotmail.com

(4) Cooperativa Central Gaúcha Ltda., Rua Marquês do Pombal, № 1.854, CEP 90540-000 Porto Alegre, RS, Brazil.

E-mail: thiagopereira@zootecnista.com.br

(5) Universidade Federal do Rio Grande do Sul, Departamento de Zootecnia, Faculdade de Agronomia, Rua Bento Gonçalves, ํㅜ 7.712, CEP 91540-000 Porto Alegre, RS, Brazil.

E-mail: feijo.fernanda@gmail.com

(6) Universidade Federal de Santa Maria, Departamento de Zootecnia e Ciências Biológicas. Campus Palmeira das Missões, Avenida Independência, oㅡ 3,751, CEP 98300000 Palmeira das Missões, RS, Brazil.

E-mail: rzvaz@terra.com.br

$\bowtie$ Corresponding author

Received

April 08, 2020

Accepted

April 15, 2020

How to cite

COSTA, P.T.; MENDONÇA, G. de; BRUM, L.P.; VIEIRA, T.P.; FEIJÓ, F.D.; VAZ, R.Z. Body mass index, energy reserves, and tissue composition of cuts of Corriedale lambs. Pesquisa Agropecuária Brasileira, v.55, e01908, 2020. DOI: https://doi.org/10.1590/S1678-3921. pab2020.v55.01908.

\section{Body mass index, energy reserves, and tissue composition of cuts of Corriedale lambs}

\begin{abstract}
The objective of this work was to identify relationships of the body mass index (BMI) with the body energy reserves and tissue composition of shoulder and leg cuts of Corriedale lambs. Twenty-two sheep with average age of 18 months were used. Linear regressions were determined between the studied characteristics. The mean body mass, body condition score (BCS), and BMI were $49.09 \pm 7.8 \mathrm{~kg}, 2.69 \pm 0.81$, and $10.66 \pm 0.99$, respectively. The BMI was correlated with the BCS $(r=0.51)$ and internal fat $(r=0.81)$. Multiple linear equations, involving BMI and BCS, yielded correlation coefficients between 0.50 and 0.76 , with significant values for all studied characteristics. The body mass index allows estimating the body energy reserves of Corriedale sheep.
\end{abstract}

Index terms: Ovis aries, body condition score, body fat, body measurements.

\section{Índice de massa corporal, reservas de energia e composição tecidual de cortes de cordeiros Corriedale}

Resumo - O objetivo deste trabalho foi identificar relações do índice de massa corporal (IMC) com as reservas energéticas corporais e a composição tecidual de cortes da paleta e do pernil de cordeiros Corriedale. Vinte e dois cordeiros com idade média de 18 meses foram utilizados. Regressões lineares foram determinadas entre as características estudadas. A massa corporal

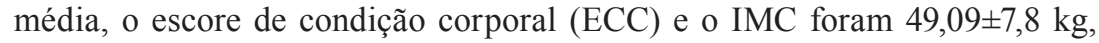
$2,69 \pm 0,81$ e $10,66 \pm 0,99$, respectivamente. O IMC correlacionou-se ao ECC $(\mathrm{r}=0,51)$ e à gordura interna total $(\mathrm{r}=0,81)$. Equações lineares múltiplas que envolveram o IMC e o ECC forneceram coeficientes de correlação entre 0,50 e 0,76 , com valores significativos para todas as características estudadas. $\mathrm{O}$ índice de massa corporal permite estimar as reservas de energia corporal de ovinos Corriedale.

Termos para indexação: Ovis aries, escore de condição corporal, gordura corporal, medidas corporais.

The Corriedale sheep originated from New Zealand, from crosses aiming at a dual-purpose breed, is used in the production of quality wool and meat (Osório et al., 2016). Currently, this breed is distributed worldwide and is the most numerous in southern South America.

As to Corriedale meat quality, data on carcass composition is increasingly important (Lemes et al., 2014), since the proportion of different tissues affects the carcass nutritional value (Scollan et al., 
2014). Tissue dissection is the main European reference standard for the approval of carcass classification procedures (Nissen et al., 2006), and it is one of the most widely used methods around the world. However, it is a very time-consuming and destructive process, which leads to unnecessary carcass losses (Xiong et al., 2017).

The BMI represents an energy reserve index and a reference for the possible occurrence of various diseases (NCD-RisC, 2017). Recently research has sought to correlate BMI with body reserves in goats and sheep (Tanaka et al., 2012; Chavarría-Aguilar et al., 2016), as well as their influence on productivity indices (Ptáček et al., 2018). These studies evidence a close relationship between BMI and body composition of animals, and they suggest its use as a noninvasive technique to predict the composition of small ruminant carcasses.

Sheep shoulders and legs show a high coefficient of correlation with the total carcass composition, and together they represent more than $50 \%$ of the total carcass weight (Osório \& Osório, 2005). However, no studies have related the tissue composition of these cuts with BMI so far.

The objective of this work was to identify relationships of the BMI with the body energy reserves and tissue composition of shoulder and leg cuts of Corriedale lambs.

The study was carried out at a private farm, in the municipality of Dom Pedrito (31 $\left.49^{\prime} 12^{\prime \prime} \mathrm{S}, 53^{\circ} 28^{\prime} 08^{\prime \prime} \mathrm{W}\right)$, in the state of Rio Grande do Sul (RS), Brazil. The experiment was approved by the Ethics Committee on Animal Experimentation (CEEA) of Universidade Federal de Pelotas (approval no. 7.886), and all procedures followed the recommendations for animal welfare and humane methods for animal slaughter.

Twenty-two castrated male lambs of the Corriedale breed, with average 18 months of age, clinically healthy, and with $31.2-60.0 \mathrm{~kg}$ mass were used in the experiment. The lambs showed different body condition scores (BCS), as follows: from 1 to 4 , in an 1 to 5 scale; and 0.5-point intervals, in which 1 corresponded to a too thin lamb, and 5 to a too fat lamb (Osório \& Osório, 2005). The animals were raised in a native pasture of the Pampa biome, in the extensive grazing system.

Prior to slaughter, the lambs were fasted for 18 hours, and water was offered to them ad libitum. After this time, live weight at slaughter $(\mathrm{kg})$ and body condition score (BCS) were determined, and the following morphometric measurements (m) were taken: height at withers (distance between withers and distal forelimb region), and body length (distance between the cervicothoracic joint and the first coccygeal vertebra).

The BCS evaluation was performed according to the methodology described by Osório \& Osório (2005). Body mass index (BMI) was calculated according to Tanaka et al. (2012): BMI $=(\mathrm{BW} / \mathrm{WH} / \mathrm{BL}) / 10$, in which: BMI is the body mass index; $\mathrm{BW}$ is the body weight $(\mathrm{kg})$; $\mathrm{WH}$ is the height at withers $(\mathrm{m})$; and $\mathrm{BL}$ is the body length $(\mathrm{m})$.

The slaughter was carried out in a slaughterhouse under state inspection and subjected to the norms prescribed by the Brazilian Animal Inspection System (Brasil, 2017). After bleeding and evisceration, the weights of the warm carcass and all noncarcass components were determined. The total internal fat (IF, internal adipose tissue) was calculated from the sum of the pelvic fat (adipose tissue located around the kidneys and pelvic region) with the fat present between the other internal organs (omental and mesenteric adipose tissue).

After slaughtering, the carcasses were stored in a cold room at $1{ }^{\circ} \mathrm{C}$, for 24 hours; then, they were cut into 5 pieces: neck, shoulder, rib, leg, and loin. Each cut was weighed, labeled, and individually stored in plastic containers, in a freezer at $-18^{\circ} \mathrm{C}$.

The tissue composition analysis was performed on the shoulder and leg cuts. The shoulder - comprised by a part of the forelimb, including the muscles of the scapula, humerus, radius, ulna, and carpus - was cut in the distal portion, at the middle portion of the carpal bones. The leg - comprised by the bone base of the tarsus, tibia, femur, ischium, ilium, and pubis was cut at the joint of the last lumbar and first sacral vertebra, and at the tarsometatarsal junction.

The laboratory analyses were carried out on the carcass and meat laboratories of the Department of Animal Science, of Universidade Federal de Pelotas, Capão do Leão, RS, Brazil, during the year 2013. The cuts were dissected with a scalpel and tweezers. The total fat tissue composition was determined, including the subcutaneous fat (external fat located at the top of the cut) and the intermuscular fat (all fat associated with muscles) (Lemes et al., 2014). The muscles include total dissected muscles, after the complete removal of

Pesq. agropec. bras., Brasília, v.55, e01908, 2020

DOI: 10.1590/S1678-3921.pab2020.v55.01908 
all adhered, subcutaneous and intermuscular fats; the bones were dissected after the complete removal of all muscles and adhered fat; and other tissues included fascia, tendon, lymph node, and large vessels. The tissue components were individually weighed, to be expressed in relation to the total weight of the cuts.

A descriptive analysis (arithmetic mean, standard deviation, maximum and minimum values) of the data was performed, and the relationships between BMI, energy reserves, and body components of the different cuts were estimated. The linear regressions were calculated between BMI and BCS, shoulder weight (SW), shoulder muscle (SM), shoulder fat (SF), leg weight (LW), leg muscle (LM), leg fat (LF), and IF, using the BioEstat software, version 5.3 (Ayres et al., 2007 ), at $5 \%$ probability.

The BMI found in the present study (Table 1) corroborates the results of Chavarría-Aguilar et al. (2016), who first investigated the BMI use in sheep and who found a BMI of $10.84 \pm 1.98$ for the Pelibuey breed. Still, our study corroborates the results obtained by Ptáček et al. (2018), who studied the relationship of BMI with the productive aspects of Wallachian sheep, with 1.8 BCS mean value, and found BMI of $8.78 \pm 1.1$. These reports show the close relationship between the mean BCS and BMI values in different sheep breeds and biotypes kept in different breeding systems, which

Table 1. Descriptive analysis of data of Corriedale sheep.

\begin{tabular}{llccc}
\hline $\begin{array}{c}\text { Vari- } \\
\text { able }\end{array}$ & \multicolumn{1}{c}{ Description } & $\begin{array}{c}\text { Mean }( \pm \\
\text { SD })^{(1)}\end{array}$ & $\begin{array}{c}\text { Maxi- } \\
\text { mum }\end{array}$ & $\begin{array}{c}\text { Mini- } \\
\text { mum }\end{array}$ \\
\hline BMI & Body mass index $\left(\mathrm{kg} \mathrm{m}^{-2}\right)$ & $10.66( \pm 0.99)$ & 12.42 & 8.46 \\
BW & Body weight $(\mathrm{kg})$ & $49.09( \pm 7.8)$ & 60.00 & 31.20 \\
BCS & Body condition score $(1-5)$ & $2.69( \pm 0.81)$ & 4.0 & 1.0 \\
SW & Shoulder weight $(\mathrm{kg})$ & $2.08( \pm 0.51)$ & 3.01 & 1.11 \\
SM & Shoulder muscle $(\mathrm{kg})$ & $1.07( \pm 0.27)$ & 1.57 & 0.72 \\
SF & Shoulder fat $(\mathrm{kg})$ & $0.39( \pm 0.17)$ & 0.72 & 0.12 \\
SB & Shoulder bone $(\mathrm{kg})$ & $0.33( \pm 0.11)$ & 0.45 & 0.25 \\
LO & Other shoulder tissues $(\mathrm{kg})$ & $0.26( \pm 0.17)$ & 0.34 & 0.17 \\
LW & Leg weight $(\mathrm{kg})$ & $2.74( \pm 0.57)$ & 4.4 & 1.68 \\
LM & Leg muscle $(\mathrm{kg})$ & $1.49( \pm 0.32)$ & 2.28 & 0.94 \\
LF & Leg fat $(\mathrm{kg})$ & $0.44( \pm 0.15)$ & 0.76 & 0.13 \\
LB & Leg bones $(\mathrm{kg})$ & $0.49( \pm 0.18)$ & 0.56 & 0.34 \\
LO & Other leg tissues $(\mathrm{kg})$ & $0.29( \pm 0.21)$ & 0.38 & 0.21 \\
$\mathrm{IF}$ & Internal fat $(\mathrm{kg})$ & $2.12( \pm 0.97)$ & 3.76 & 0.12 \\
\hline
\end{tabular}

${ }^{(1)} \mathrm{SD}$, standard deviation. permits to suggest that the overall BMI of the species oscillates between 6 and 16, with a mean close to 11 .

The lambs in the present study were of the same breed, sex, and age, with differences for live weight and BCS. The muscular components (SM and LM), and especially those of the adipose tissue (SF, LF, and IF) were the body components with the greatest amplitude of variation. Thus, in a group of contemporary animals of the same genetic basis, differences for live weight and BCS impact the volume of muscle and fat tissue in carcasses.

The BMI showed correlation with BCS $[\mathrm{r}=0.51$ $(\mathrm{p}<0.05)]$, IF $[\mathrm{r}=0.81(\mathrm{p}<0.01)]$, and BW $[\mathrm{r}=0.67$ $(p<0.05)]$. The simple linear equations showed significant values, at $5 \%$ probability, for the relationships between $\mathrm{BMI}$ and the characteristics BCS, SW, SM, SF, LF, and IF, with coefficients of determination $\left(\mathrm{R}^{2}\right)$ ranging from 0.20 to 0.65 (Table 2 ). The multiple linear regression equations were more efficient, with coefficients of determination between 0.50 and 0.76 . The energy reserves of sheep can be measured by BMI (Chavarría-Aguilar et al., 2016)

Table 2. Regression equations developed for the relationships of body mass index (BMI) and body condition score (BCS) with the constituents of shoulders and legs in Corriedale sheep.

\begin{tabular}{lcc}
\hline Linear regression & $\mathrm{R}^{2}$ & $\mathrm{p}$-value \\
\hline $\mathrm{BCS}=-1.7888+(0.42 \times \mathrm{BMI})$ & 0.26 & 0.0176 \\
$\mathrm{SW}=-0.9443+(0.2838 \times \mathrm{BMI})$ & 0.30 & 0.0103 \\
$\mathrm{SW}=-0.0564+(0.0753 \times \mathrm{BMI})+(0.4964 \times \mathrm{BCS})$ & 0.76 & $<0.0001$ \\
$\mathrm{SM}=-0.2453+(0.1234 \times \mathrm{BMI})$ & 0.20 & 0.0403 \\
$\mathrm{SM}=0.2471+(0.0078 \times \mathrm{BMI})+(0.2753 \times \mathrm{BCS})$ & 0.70 & $<0.0001$ \\
$\mathrm{SF}=-0.7160+(0.1034 \times \mathrm{BMI})$ & 0.34 & 0.0037 \\
$\mathrm{SF}=-0.5083+(0.0547 \times \mathrm{BMI})+(0.1161 \times \mathrm{BCS})$ & 0.60 & 0.0004 \\
$\mathrm{LW}=0.6706+(0.1944 \times \mathrm{BMI})$ & 0.11 & 0.1350 \\
$\mathrm{LW}=1.5836+(-0.02 \times \mathrm{BMI})+(0.5104 \times \mathrm{BCS})$ & 0.50 & 0.0022 \\
$\mathrm{LM}=0.2511+(0.1226 \times \mathrm{BMI})$ & 0.15 & 0.0790 \\
$\mathrm{LM}=0.7692+(0.0009 \times \mathrm{BMI})+(0.2896 \times \mathrm{BCS})$ & 0.57 & 0.0007 \\
$\mathrm{LF}=-0.4250+(0.0948 \times \mathrm{BMI})$ & 0.28 & 0.0134 \\
$\mathrm{LF}=-0.1692+(0.0348 \times \mathrm{BMI})+(0.1430 \times \mathrm{BCS})$ & 0.60 & 0.0005 \\
$\mathrm{IF}=-6.8157+(0.8384 \times \mathrm{BMI})$ & 0.65 & $<0.0001$ \\
$\mathrm{IF}=-6.1167+(0.6742 \times \mathrm{BMI})+(0.3907 \times \mathrm{BCS})$ & 0.72 & $<0.0001$ \\
\hline
\end{tabular}

SW, shoulder weight; SM, shoulder muscle; SF, shoulder fat; LW, leg weight; LM, leg muscle; LF, leg fat; IF, internal fat; and $\mathrm{R}^{2}$, determination coefficient. 
and by BCS (Osório \& Osório, 2005) in isolation. However, the results of the present study indicate that the concomitant use of BMI and BCS allows of a more accurate estimation of body reserves, constituting a very promising alternative for estimating the energy reserves and body composition of sheep.

The BMI shows a near relationship with body energy reserves and tissue composition of shoulders and legs, and it can estimate the body reserves of Corriedale sheep. The BMI, together with body condition score, can be used as a predictor of tissue composition of shoulder and leg cuts of 18-month-old Corriedale lambs.

\section{Acknowledgments}

To Conselho Nacional de Desenvolvimento Científico e Tecnológico (CNPq), for financial support; to Coordenação de Aperfeiçoamento de Pessoal de Nível Superior (Capes), for financial support (Finance code 001); and to Fazenda São Pedro, for permitting the access to facilities and for providing the technical support.

\section{References}

AYRES, M.; AYRES JR., M.; AYRES, D.L.; SANTOS, A. de A.S. dos. BioEstat 5.3: aplicações estatísticas nas áreas das Ciências Bio-médicas. Belém: Sociedade Civil Mamirauá, 2007. 364p.

BRASIL. Ministério da Agricultura, Pecuária e Abastecimento. Sistema Brasileiro de Inspeção Animal. 2017. Available at: $<$ http://www.agricultura.gov.br/assuntos/inspecao/produtosanimal/sisbi-1>. Accessed on: Aug. 212018.

CHAVARRÍA-AGUILAR, L.M.; GARCÍA-HERRERA, R.A.; SALAZAR-CUYTUN， R.; CHAY-CANUL， A.J.; CASANOVA-LUGO, F.; PIÑEIRO-VÁZQUEZ, A.T.; AGUILAR-CABALLERO, A.J. Relationship between body fat depots and body mass index in Pelibuey ewes. Small Ruminant Research, v.141, p.124-126, 2016. DOI: https://doi.org/10.1016/j. smallrumres.2016.07.014.

LEMES, J.S.; OSÓRIO, M.T.M.; OSÓRIO, J.C.S.; GONZAGA, S.S.; MARTINS, L.S.; ESTEVES, R.M.G.; LEHMEN, R.I. Características da carcaça e da carne de cordeiros Corriedale manejados em duas alturas de milheto. Archivos de Zootecnia, v.63, p.161-170, 2014. DOI: https://doi.org/10.4321/S000405922014000100016 .

NCD-RisC. NCD Risk Factor Collaboration. Worldwide trends in body-mass index, underweight, overweight, and obesity from 1975 to 2016: a pooled analysis of 2416 population-based measurement studies in 128.9 million children, adolescents, and adults. Lancet, v.390, p.2627-2642, 2017. DOI: https://doi.org/10.1016/S01406736(17)32129-3

NISSEN, P.M.; BUSK, H.; OKSAMA, M.; SEYNAEVE, M.; GISPERT, M.; WALSTRA, P.; HANSSON, I.; OLSEN, E. The estimated accuracy of the EU reference dissection method for pig carcass classification. Meat Science, v.73, p.22-28, 2006. DOI: https://doi.org/10.1016/j.meatsci.2005.10.009.

OSÓRIO, J.C. da S.; OSÓRIO, M.T.M. Produção de carne ovina: técnicas de avaliação in vivo e na carcaça. 2.ed. Pelotas: Universidade Federal de Pelotas, 2005. 82p.

OSÓRIO, J.C. da S.; OSÓRIO, M.T.M.; FERREIRA, O.G.L.; GONÇALVES, M. da S. Raças ovinas. In: FERREIRA, O.G.L.; GONÇALVES, M.S. (Org.). Ovinocultura. Pelotas: Educat, 2016. p.33-60.

PTÁČEK, M.; MILERSKI, M.; SCHMIDOVÁ, J.; DUCHÁČEK, J.; TANČIN, V.; UHRINČAT, M.; HAKL, J.; STÁDNÍK, L. Relationship between body mass index, body energy reserves, milk, and meat production of original Wallachian sheep. Small Ruminant Research, v.165, p.131-133, 2018. DOI: https://doi.org/10.1016/j.smallrumres.2018.04.001.

SCOLLAN, N.D.; DANNENBERGER, D.; NUERNBERG, K.; RICHARDSON, I.; MACKINTOSH, S.; HOCQUETTE, J.-F.; MOLONEY, A.P. Enhancing the nutritional and health value of beef lipids and their relationship with meat quality. Meat Science, v.97, p.384-394, 2014. DOI: https://doi.org/10.1016/j. meatsci.2014.02.015.

TANAKA, T.; AKABOSHI, N.; INOUE, Y.; KAMOMAE, H.; KANEDA, Y. Corrigendum to "Fasting-induced suppression of pulsatile luteinizing hormone secretion is related to body energy status in ovariectomized goats" [Anim. Reprod. Sci. 72 (2002) 185-196]. Animal Reproduction Science, v.132, p.111, 2012. DOI: https://doi.org/10.1016/j.anireprosci.2012.05.001.

XIONG, Z.; SUN, D.-W.; PU, H.; GAO, W.; DAI, Q. Applications of emerging imaging techniques for meat quality and safety detection and evaluation: a review. Critical Reviews in Food Science and Nutrition, v.57, p.755-768, 2017. DOI: https://doi.org /10.1080/10408398.2014.954282. 